\title{
SECONDARY HARDENING OF HOMOGENEOUS T24 WELDS AFTER SHORT-TERM ANNEALING AT 450 AND $530^{\circ} \mathrm{C}$
}

\author{
Iva ŠíPOVÁ, Daniel BARTONĚK, Vlastimil VODÁREK \\ VŠB -TU of Ostrava, Faculty of Materials Science and Technology, 17. listopadu 15, 70800 Ostrava- \\ Poruba, Czech Republic, EU, iva.sipova.st@vsb.cz
}

https://doi.org/10.37904/metal.2020.3507

\begin{abstract}
The T24 steel grade has been frequently used for the construction of membrane walls in modern power plant boilers. This steel grade has been developed with the intention of welding without post weld heat treatment. However, commissioning of new units of power plants into service revealed many defects in homogeneous T24 welds. Several remedial measures have been proposed. One of them represents annealing of boilers before putting them into service at $450^{\circ} \mathrm{C}$.

This paper deals with characterization of microhardness and microstructure of homogeneous peripheral butt T24 welds after annealing at $450^{\circ} \mathrm{C}$ for 48 hours and subsequent annealing at $530^{\circ} \mathrm{C}$ for 10 hours. The results revealed that annealing at $450{ }^{\circ} \mathrm{C}$ led to a further increase of hardness in overheated parts of heat affected zones of homogeneous T24 welds. Subsequent short-term annealing at temperature of $530{ }^{\circ} \mathrm{C}$, which corresponded to the typical temperature of boilers commissioning, caused a significant effect of secondary hardening in overheated parts of heat affected zones of homogeneous T24 welds. TEM investigations were carried out in order to explain this effect.
\end{abstract}

Keywords: Homogeneous welds, T24 steel, microstructural stability, microhardness, annealing, TEM

\section{INTRODUCTION}

The heat resistant T24 steel grade (7CrMoVTiB 10-10) has been developed in Germany for welding without post weld heat treatment (PWHT). Research programmes were focused on quality of weldments manufactured by welding technologies using protective gas, creep properties and corrosion behaviour of welds and their thermal stability. Based on the results of qualification programmes, it was reported that thin wall weldments made of this steel grade can be used without PWHT. Tubes made of this steel are frequently used for construction of membrane walls in modern boilers for thermal power plants [1].

However, start-up procedures of many new plant units across whole Europe have been accompanied by the formation of cracks in homogeneous T24 welds. The dominant mechanism of damage of these welds in the as-welded state (without PWHT) has been identified as hydrogen induced stress corrosion cracking [1]. This type of cracking needs a synergy of three factors: corrosive medium, critical levels of internal stresses and high hardness in critical parts of welds, especially in overheated parts of heat affected zones (CG HAZ) of base materials and in weld metal. Cracks can be oriented parallel or longitudinal to the axis of welds. Cracks can be transcrystalline as well as intercrystalline. They are initiated on the side of a contact of welds with water environment. Cracks usually form in the HAZ of the weld root and spread across the HAZ and weld metal towards the outer surface of tubes [2].

Welding is accompanied by fast dissolution of fine particles of minor phases in the HAZs of base materials [3]. In the state after welding these parts of welds as well as weld metal are oversaturated by strong carbide and nitride forming elements. Re-precipitation of fine carbides and nitrides of titanium and vanadium occurring at 
temperatures above ca $500{ }^{\circ} \mathrm{C}$ could result in harmful secondary hardening. From this point of view some authors believe that cracks in homogeneous T24 welds are rather annealing cracks [3]. Special measures have been developed and implemented to reduce the risk of homogeneous T24 welds damage: annealing of boilers at $450-500{ }^{\circ} \mathrm{C}$ before commissioning, reduced oxygen content in water (below $20 \mathrm{ppm}$ ) and steam, increased $\mathrm{pH}$ value of water, no chemical cleaning of T24 parts, optimization of a start-up procedure and a special repair concept for homogeneous T24 welds [2].

The aim of this paper is to characterize changes in hardness and microstructure in critical parts of homogeneous T24 welds after several regimes of low temperature annealing, closely related to recommended start-up procedures of boilers. It is expected that annealing of boilers at $450^{\circ} \mathrm{C}$ could reduce internal stresses in welds in the as-welded state. However, oversaturation of solid solution in the HAZs and in weld metal should be largely preserved. In these parts of welds we can expect secondary hardening effect during the subsequent commissioning of power plant blocks at temperatures of ca $530-560{ }^{\circ} \mathrm{C}$. This could facilitate the formation of annealing cracks.

\section{EXPERIMENTAL MATERIAL AND TECHNIQUES}

Investigations were carried out on circumferential butt welds of T24 tubes with the diameter of $43 \mathrm{~mm}$ and the wall thickness of $6 \mathrm{~mm}$. Chemical composition of T24 tubes is stated in Table 1.

Table 1 Cast analysis of T24 steel, mass \%

\begin{tabular}{ccccccccc}
\hline $\mathrm{C}$ & $\mathrm{Mn}$ & $\mathrm{Si}$ & $\mathrm{P}$ & $\mathrm{S}$ & $\mathrm{Cr}$ & $\mathrm{Mo}$ & $\mathrm{V}$ & $\mathrm{Ti}$ \\
\hline 0.08 & 0.60 & 0.25 & 0.016 & 0.002 & 2.43 & 0.99 & 0.23 & 0.093 \\
\hline
\end{tabular}

Quality heat treatment of T24 tubes was as follows: $1000^{\circ} \mathrm{C} / 1$ hour/ air $+760^{\circ} \mathrm{C} / 6$ hours/ air.

TIG welding technology (method 141) was applied for the production of welds. Preheating temperature was $150-200^{\circ} \mathrm{C}$ and interpass temperature was $200^{\circ} \mathrm{C}$. Wire made of a W Z CrMo2VTi steel (Union I P24) was applied as a filler material. Welds were formed by three beads. In the as-welded state microhardness of the base material reached about 200 HV0.2 [4]. The peak of microhardness was observed in the HAZ, especially in the CG HAZ, where the maximum value reached $404 \mathrm{HV}$ 0.2. Microhardness of bainite in weld metal moved around $350 \mathrm{HV}$ 0.2. Microstructure in all parts of the weld corresponded to bainite. In the CG HAZ a small fraction of martensite could be present.

Experimental activities were focused on the following specimens: Specimen A: after annealing at $450{ }^{\circ} \mathrm{C} / 48$ hours and Specimen $B$ : after annealing at $450{ }^{\circ} \mathrm{C} / 48$ hours $+530^{\circ} \mathrm{C} / 10$ hours. Hardness and microstructure evaluation were carried out on longitudinal sections through weldments. Profiles of microhardness HV0.2 were measured with a step of $0.5 \mathrm{~mm}$ in the middle thickness of weldments. Microstructure characterization was carried out using a light microscope Olympus GX51. Microstructure was revealed by etching in a $4 \%$ Nital solution. Precipitation in the CG HAZ was characterized using carbon extraction replicas on a transmission electron microscope JEM 2100. Energy dispersive microanalysis (EDX) was used for characterization of minor phases.

\section{RESULTS AND DISCUSSION}

\subsection{Microhardness profile}

Figure 1 shows macroetching of the specimen B. As evident, the width of the HAZs is several millimeters. Microhardness HV0.2 profiles across the welds in specimens A and B are shown in Figures 2 and $\mathbf{3}$, 
respectively. In the specimen A, the critical level of hardness (i.e. ca $350 \mathrm{HV}$ ) was exceeded in the HAZ, especially in the CG HAZ, where it locally exceeded 400 HV0.2 [4].

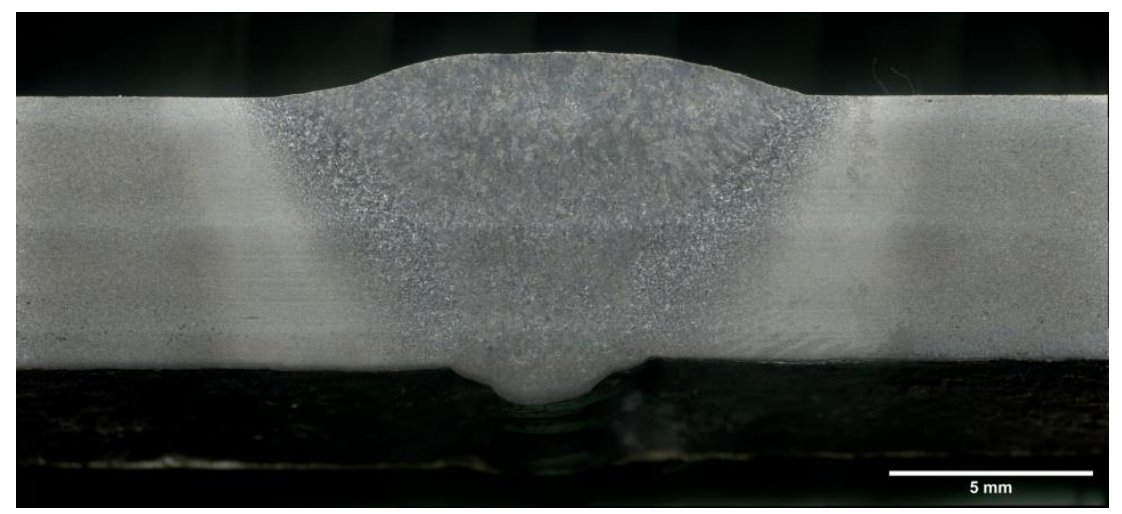

Figure 1 Macroetching of the homogeneous T24 weld, specimen B

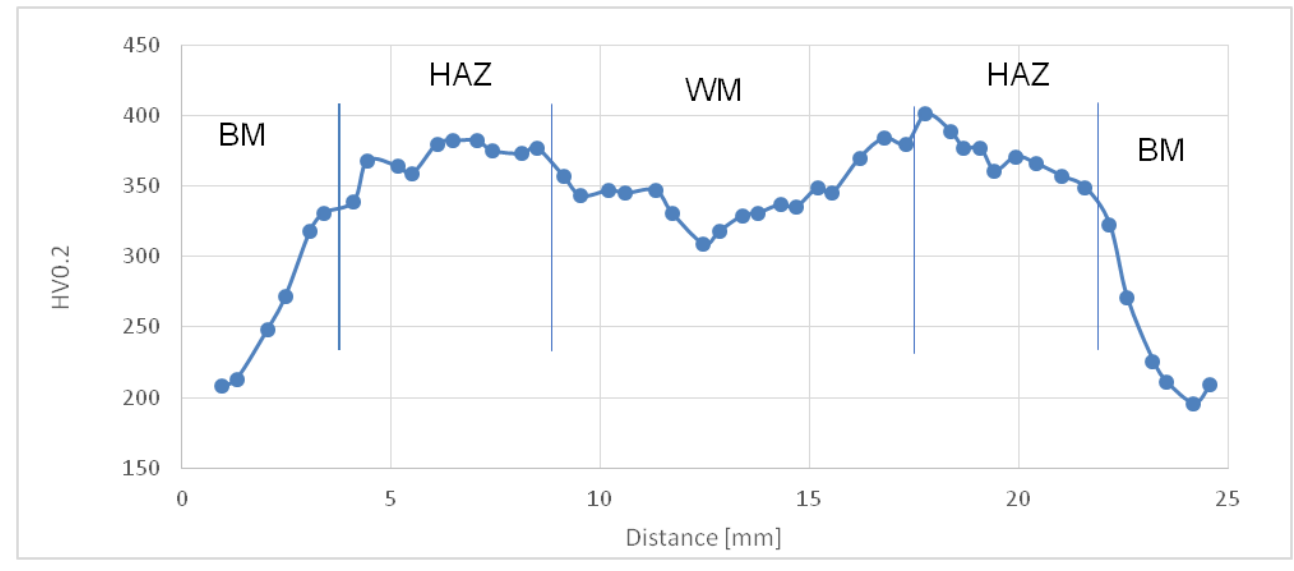

Figure 2 Microhardness HV0.2 profile across the specimen A

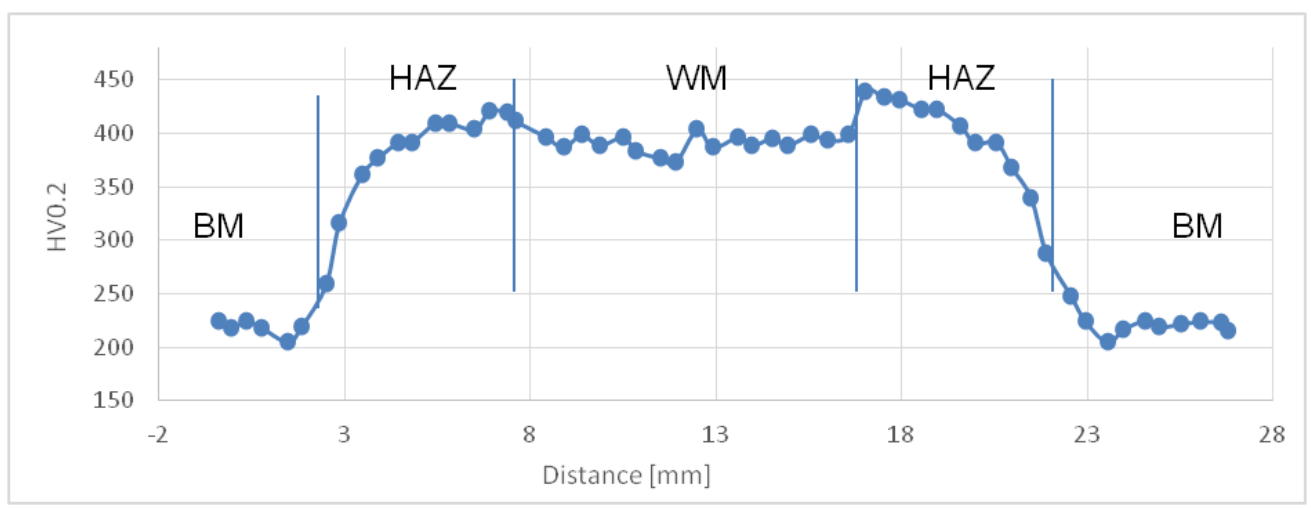

Figure 3 Microhardness HV0.2 profile across the specimen B

\subsection{Microstructure evolution}

\subsubsection{Specimen A}

Microstructure of the base metal (BM) consists of heavy tempered bainite. Minor phases present in the matrix after quality heat treatment were identified as $\mathrm{M}_{23} \mathrm{C}_{6}, \mathrm{M}_{7} \mathrm{C}_{3}$ and $\mathrm{MX}$ [3]. At the peak temperature of the welding cycle all particles of minor phases dissolved in austenite, except for coarse MX particles rich in titanium. The 
prior austenite grain size in the $C G H A Z$ reached the value of $G=5$, while in the base material it was $G=7$, Figures $\mathbf{4 a}$ and $\mathbf{4 b}$ [4]. During cooling of the weld, austenite in the CG HAZ decomposed on bainite and a small fraction of microstructure was probably formed by martensite. Products of austenite decomposition in this part of the HAZ were oversaturated by alloying elements. This creates preconditions for secondary hardening of T24 welds during subsequent annealing.

In the fine grained part of the HAZ (FG HAZ) temperatures during welding cycle were above $A_{c 3}$, but significantly lower than in the CG HAZ. In this part of the weld minor phases present in the initial microstructure of BM dissolved only partly. In the FG HAZ austenite decomposed to bainite which was partly oversaturated by alloying elements. In the intercritical region of the HAZ (IC HAZ) the initial microstructure transformed to austenite only partly and the fraction of dissolved precipitates was lower than that in the FG HAZ. Heterogeneous microstructure of the FG HAZ consisted of heavy tempered ferrite and islands of bainite formed by decomposition of austenite. As-cast microstructure of the weld metal was bainitic. Light microscopy did not reveal any visible changes in the weld microstructure after annealing of the specimen $A$ at $450{ }^{\circ} \mathrm{C}$.

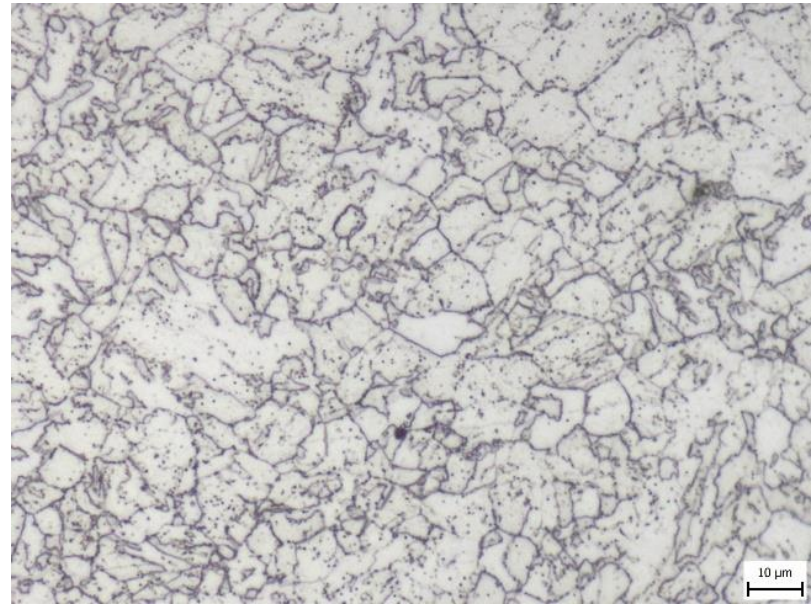

a)

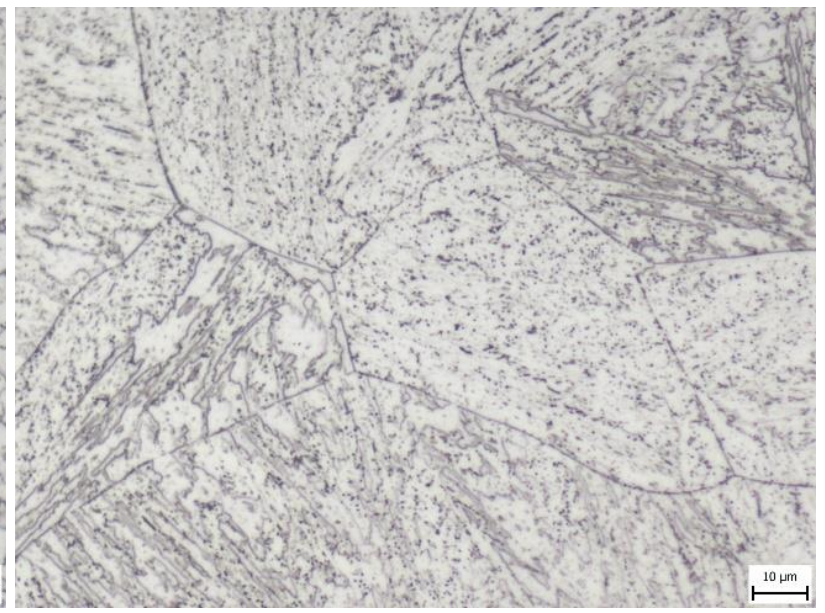

b)

Figure 4 Microstructure of the base material - heavy tempered bainite, b) microstructure of the CG HAZ bainite and martensite, specimen $A$

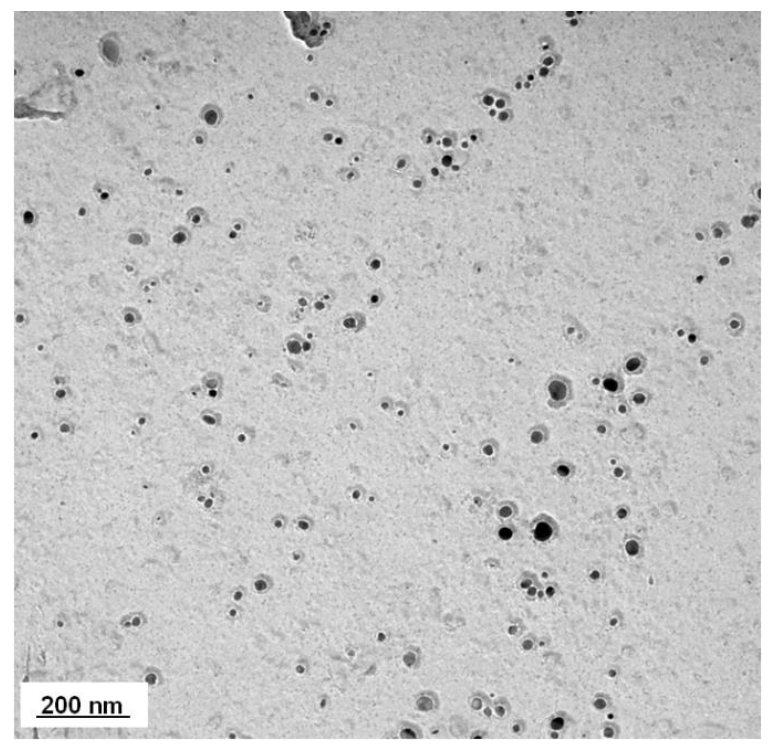

a)

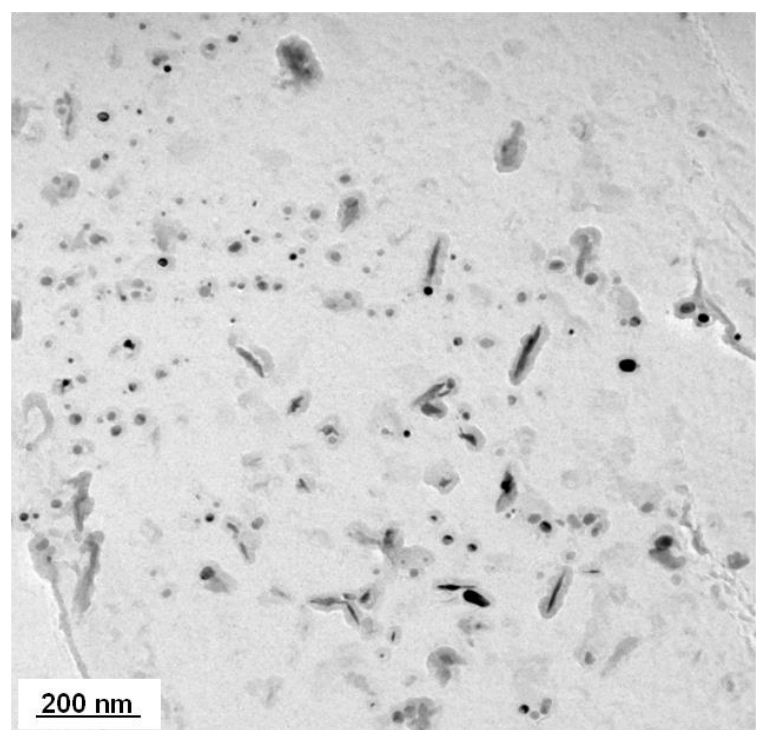

b)

Figure 5 Precipitation in the CG HAZ, carbon extraction replica, specimen A, a) MX particles, b) MX particles and needles of cementite 
Precipitation in the CG HAZ was studied using TEM. Thermal simulations of the CG HAZ indicated that during the welding thermal cycle all precipitates in T24 BM dissolved, except for coarse titanium rich MX particles [3]. Figure 5a shows very fine precipitates that were present in the CG HAZ of the specimen A. Using EDX analysis it was proved that these particles were rich in titanium and contained variable amounts of molybdenum. Chemical composition of typical particles is shown in Table 2. Such particles correspond to the MX phase. Furthermore, needles of cementite were present in bainite, Figure $\mathbf{5 b}$. These needles probably precipitated during annealing at $450{ }^{\circ} \mathrm{C}$, globular cementite particles were part of bainite. Increase in microhardness HV0.2 in the CG HAZ after annealing at $450{ }^{\circ} \mathrm{C}$ for 48 hours can be attributed to precipitation of fine particles from the supersaturated solid solution.

Table 2 Results of semiquantitative EDX analyses of fine precipitates, mass \%

\begin{tabular}{cccccc}
\hline No. & $\mathrm{Ti}$ & $\mathrm{V}$ & $\mathrm{Cr}$ & $\mathrm{Fe}$ & $\mathrm{Mo}$ \\
\hline 1 & 38.9 & 13.3 & 3.2 & 2 & 42.6 \\
2 & 65.5 & 4.6 & 1.1 & 8.3 & 20.5 \\
3 & 40.4 & 13.3 & 2.1 & 2.2 & 42 \\
\hline
\end{tabular}

Note: interstitial elements were not taken into account - results were normalized to $100 \%$

Neutron diffraction investigations on internal stresses in the specimen $A$ revealed that annealing at $450{ }^{\circ} \mathrm{C}$ was accompanied by only a small reduction of the peak of axial stresses in the CG HAZ (from ca $300 \mathrm{MPa}$ to ca $250 \mathrm{MPa}$ ), dislocation density in this area remained nearly the same as in the as-welded state [5].

\subsubsection{Specimen B}

Light microscopy investigations on the specimen B after annealing at $450+530{ }^{\circ} \mathrm{C}$ did not reveal any observable changes in the microstructure. Figure 6a shows typical coarse grained microstructure of the CG HAZ. TEM analysis of the CG HAZ again revealed fine precipitation of titanium rich particles MX, Figure $6 \mathbf{b}$. Furthermore, particles of cementite were present in the CG HAZ. No other minor phases were detected.

Neutron diffraction investigations on internal stresses in the specimen $B$ revealed that annealing at $450+530^{\circ} \mathrm{C}$ was accompanied by a small reduction of the peak of axial stresses in the CG HAZ (from ca $300 \mathrm{MPa}$ to ca $200 \mathrm{MPa}$ ), dislocation density in this area decreased due to recovery of the bainitic ferrite [5]. However, the results of microhardness evaluation prove that a reduction of transformation hardening in the CG HAZ was eliminated and exceeded by precipitation hardening.

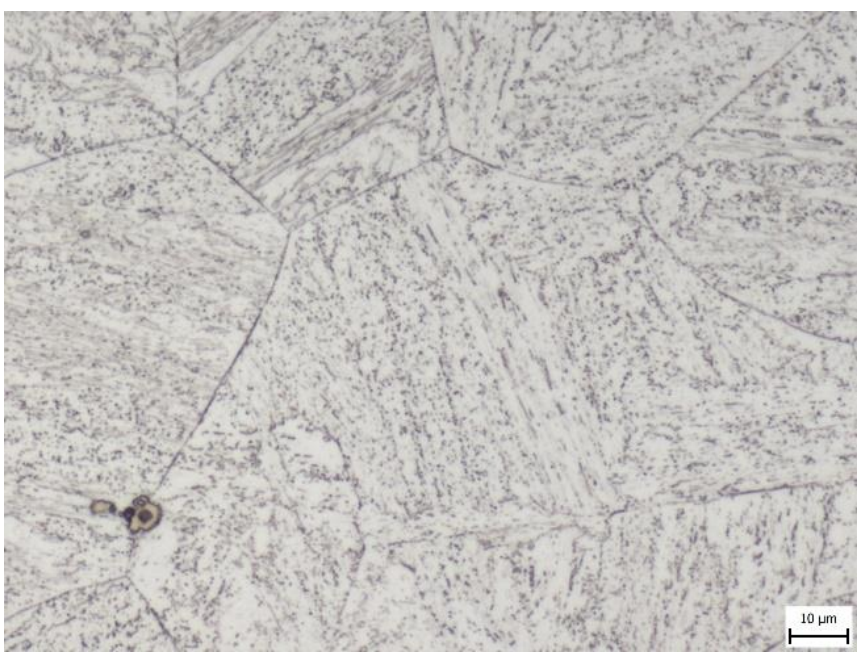

a)

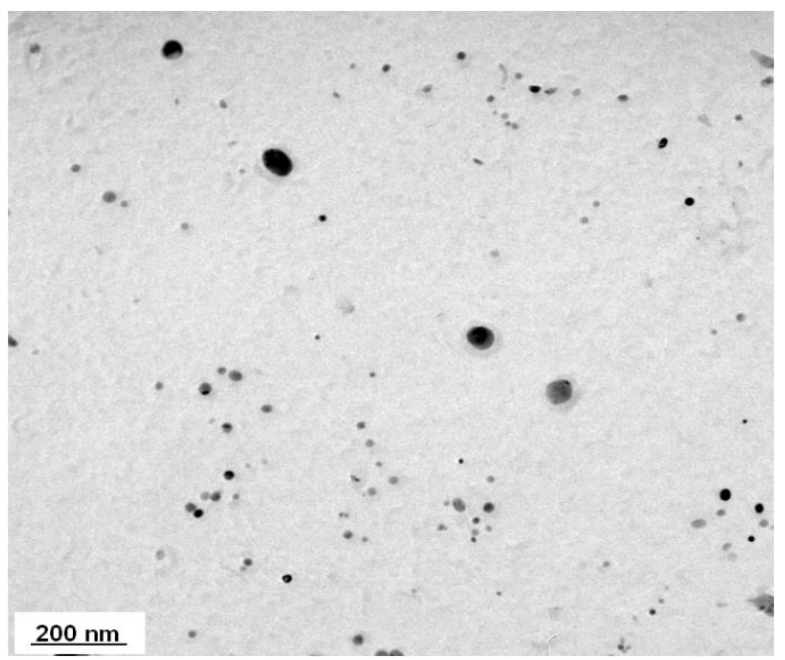

b)

Figure 6 a) Microstructure of the CG HAZ, b) TEM micrograph of precipitation in the CG HAZ, specimen B 


\section{CONCLUSION}

The results prove that preliminary annealing of T24 homogeneous welds at temperature of $450{ }^{\circ} \mathrm{C}$ for 48 hours did not prevent significant secondary hardening during subsequent annealing at $530^{\circ} \mathrm{C}-$ at the beginning of commissioning of power plant units. Annealing at $450{ }^{\circ} \mathrm{C}$ also did not lead to a significant decrease of internal stresses in welds. Evaluation of hardness and microstructural characterization revealed that short-term annealing at $530{ }^{\circ} \mathrm{C}$ was accompanied by recovery of bainite in the CG HAZ but this decline in transformation hardening was eliminated and exceeded by a significant contribution of precipitation hardening. The results obtained confirm the presumption that secondary hardening may play a significant role in the formation of cracks in homogeneous T24 welds.

\section{ACKNOWLEDGEMENTS}

This paper was created with the financial contribution of the projects Student Grant Competition "SP2020/58 Development of methods of structural analysis, testing of mechanical properties and non-destructive testing of advanced materials", "SP2020/39 Specific research in the metallurgical, materials and process engineering" and the project No. CZ.02.1.01/0.0/0.0/17_048/0007373 "Damage

Prediction of Structural Materials" within the Research, Development and Education Operational Programme financed by the European Union and from the state budget of the Czech Republic.

\section{REFERENCES}

[1] ELSEN, R., J. HANNES, G. BUNG, Ch. GÖTTE, F. NEUMANN. First operational experience with advanced materials in USC boilers of RWE generation. Leipzig: VGB Congress Power Plants, 2016.

[2] NOWACK, R., Ch. GÖTTE, S. HECKMANN. Quality management at RWE using T24 boiler material as an example. VGB Power Tech., 2011, vol. 11, pp. 1-5.

[3] SZTEFEK, R. Svařitelnost a vlastnosti svarových spojů oceli T24 (7CrMoVTiB10-10, 1.7378). Disertační práce, Ostrava: VŠB - Technická univerzita Ostrava, 2014.

[4] BARTONĚK, D. Vliv nízkoteplotního žíhání na mikrostrukturu a vlastnosti homogenních svarů z oceli T24, Diplomová práce. Ostrava: VŠB - Technická univerzita Ostrava, 2020.

[5] BOKUCHAVA, G., V. VODÁREK. Evolution of internal stresses and microstructure in homogeneous T24 welds, Technical report. Dubna: FNLP JINR, 2020. 